\title{
Economic Assessment of Sugarcane (Saccharum officinarum L.) through Intercropping
}

\author{
Abdul Rehman1", Rafi Qamar'2, Jamshaid Qamar1 \\ ${ }^{1}$ Department of Agronomy, University College of Agriculture, University of Sargodha, Sargodha, Pakistan \\ ${ }^{2}$ Agronomy Section, Central Cotton Research Institute, Sakrand, Sindh, Pakistan \\ Email: ${ }^{*}$ drabdulrehman18@yahoo.com
}

Received 28 April 2014

\section{Abstract}

Sugarcane has pronounced importance to provide sugar for more than half of the global population. World population is enhancing day-by-day and production land is in the worst situation. The cultivated land is diminishing rapidly due to urbanization, road construction, and land deterioration. This crisis demands alternate research to raise crop productivity and maximize the economic returns per unit land for feeding the gigantic population. Sugarcane is a long duration crop and gave late net economic return. Intercropping in sugarcane received much attention and need to properly manage for getting higher net return from same unit area. It is becoming popular among farming community due to resourcefully utilization of land. Intercropping has the potential to inspire the farmers to get maximum economic return per acre per annum. For intercropping, wheat, gram, soybean, and potato were used as an intercrop in September-sown sugarcane. Triple row strip planting geometry of sugarcane with four intercropped (SC + Wheat, SC + Gram, SC + Soybean, and SC + Potato) and check with sole SC was used. Sugarcane was planted during September 201112 and 2012-13 at research area University College of Agriculture, University of Sargodha, Pakistan. Randomized complete block design with three replications were used. Results showed that number of millable cane, cane diameter; unstripped and stripped cane yield and crop growth rate was significantly higher in sole sugarcane when compared with different intercrop in 2011-12 while trend was same in 2012-13. Cane diameter and un-stripped cane yield were statistically at par of intercrops SC + Soybean and SC + Potato while stripped cane yield of Sole SC and SC + Potato was statistically at par in 2012-13. In both the year of study, intercrops gave higher land equivalent ratio and net return over sole sugarcane planted while sole sugarcane gave maximum benefit cost ratio compared with other intercrops.

\section{Keywords}

World Population Stress, Sugarcane, Intercropping, Economic Return, Benefit Cost Ratio

\footnotetext{
${ }^{*}$ Corresponding author.
}

How to cite this paper: Rehman, A., Qamar, R. and Qamar, J. (2014) Economic Assessment of Sugarcane (Saccharum officinarum L.) through Intercropping. Journal of Agricultural Chemistry and Environment, 3, 24-28. 


\section{Introduction}

Sugarcane (Saccharum officinarum L.) is the main source of revenue in Pakistan after cotton and rice. It is a source of providing raw material to many allied industries and employment [1]. Sugarcane contributes $3.2 \%$ to the value added products in agriculture and $0.7 \%$ to gross domestic production [2]. Currently, the area under sugarcane is 1.12 million hectares and total production is 62.4 million tons with an average yield of 55.58 metric ton ha $^{-1}$ [2]. Despite a higher yield potential, average stripped cane yield of sugarcane in Pakistan is well below compare than sugarcane producing countries of the world [3]. There are several factors involved in yield stagnation at farmer's field. The most important cause is conventional planting method/geometry [4].

Triple row planting may be suitable and efficient planting system in saving water and reduce lodging due to easiness in inter-cultural practice and earthing-up operations [5]. Triple row strip planting plays significant role in increasing plant population and stripped cane yield [6]. Sugarcane yield and yield attributes like tillers, plant height, number of millable canes and stripped cane yield produced by $120 \mathrm{~cm}$ apart triple row trench planting was higher than $60 \mathrm{~cm}$ apart single row trenches [7]. A triple row spacing of $120 \mathrm{~cm}$ produced more total dry matter and stripped cane yield over single row and double row spacing 60 and $90 \mathrm{~cm}$ but cane quality were alike with different row spacing [8]. A triple row planting sugarcane with recommended seed rate gave maximum net income/economic returns than conventional method of planting [9].

Intercropping has been known a tremendous practice to increase stripped cane yield, maximum net returns, and better resources utilization and fulfill the demand of diversified farms. The gross monetary returns have been recognized the highest from intercropping cane with potato and lowest from pure cane [10]. The conventional methods of planting cane do not permit the intercrops to grow well due to shading and competition effect. The popularity of intercropping systems on small growers in the developing countries and the demand for more food has required intensive research on intercropping [11]. The contradictory yield results of different intercrops were found in different studies [12]-[14].

There are not much reported studies on the different intercrops in sugarcane growing areas in Pakistan. The present study was conducted with the following objective:

- To explore the yield feasibility of sugarcane yield under different intercrops and its economics.

\section{Materials and Methods}

\subsection{Experimental Site}

The study regarding intercropping in spring planted sugarcane was conducted for two year during 2011-12 and 2012-13 on a loam soil at research area University College of Agriculture, University of Sargodha $\left(32^{\circ} 04^{\prime} \mathrm{N}\right.$, $72^{\circ} 67^{\prime} \mathrm{E}$ ), Pakistan. The climate of the region is subtropical semi-arid with annual average rainfall of $400 \pm 5 \mathrm{~mm}$, and more than $70 \%$ of the rainfall occurs during June-September (Source: Agro-Metrological Lab, University of Sargodha). Mean monthly minimum temperature is $10^{\circ} \mathrm{C}$ in January and maximum temperature is $40^{\circ} \mathrm{C}$ in July. The soil is the Hafizabad series (fine-silty, mixed, hyperthermic typic calciargids) and the soil texture is loam and heavy loam [15]. Selected chemical and physical characteristics were done before sowing: $\mathrm{pH} 7.8 \pm 0.1$, electrical conductivity $2.18 \pm 0.3 \mathrm{dS} \cdot \mathrm{m}^{-1}$, soil organic matter content $0.70 \%$, total $\mathrm{N} 0.05 \%$, available phosphorus 60 $\mathrm{mg} \cdot \mathrm{kg}^{-1}$ and exchangeable potassium $80 \mathrm{mg} \cdot \mathrm{kg}^{-1}$.

\subsection{Layout and the Experimental Design}

The experiment was laid out according to triplicate randomized complete block design using three replications. Net plot size was $4.2 \mathrm{~m} \times 8.0 \mathrm{~m}$ for $120 \mathrm{~cm}$ spaced strips. The treatments comprised; sole sugarcane, SC + Wheat, SC + Gram, SC + Soybean and SC + Potato (within $120 \mathrm{~cm}$ apart). Trenches were made with the help of tractor drawn ridger.

\subsection{Crop Husbandry}

Sugarcane variety HSF-240 with seed rate of 75,000 double budded setts per hectare was sown in September during 2011-12 and 2012-13. Fertilizer was applied at the rate of 175, 115 and $115 \mathrm{~kg} \cdot \mathrm{NPK} \cdot \mathrm{ha}^{-1}$.

\subsection{Statistical Analysis}

Data were analyzed statistically using SAS [16]. The effects of intercropping were evaluated by the least signif- 
icant difference (LSD) test at $\mathrm{p} \leq 0.05$ unless otherwise mentioned. The computer package MS-Excel was used to prepare the graphs.

\section{Results and Discussion}

\subsection{Different Intercrops Effects on Sugarcane Yield and Land Equivalent Ratio}

Sole SC and different intercrops in SC had significantly effect on all yield parameters during both the year 2011-12 and 2012-13 (Table 1). In 2011-12, sole SC had significantly 8\% higher millable cane $\left(14.3 \mathrm{~m}^{-2}\right)$ compared than SC + Potato while in case of intercrops, SC + Gram gave significantly 3\%, 4\%, and 5\% higher millable cane than SC + Wheat, SC + Soybean and SC + Potato. In second year 2012-13 same trend was observed while lower number of millable cane $\left(12.9 \mathrm{~m}^{-2}\right)$ was recorded in SC + Soybean than other intercrops. Sole SC produced significantly $6 \%$ higher cane diameter than SC + Wheat. However, SC + Potato had significantly higher cane diameter than SC + Gram, SC + Soybean and SC + Wheat in 2011-12. In second year same trend was noted while cane stem diameter of SC + Potato and SC + Soybean was statistically at par with each other. In both the years of study, significantly higher unstriped cane yield $\left(121.8 \mathrm{t} \cdot \mathrm{ha}^{-1}\right.$ and $\left.120.2 \mathrm{t} \cdot \mathrm{ha}^{-1}\right)$ was noted in sole SC compared than SC + Wheat $\left(113.6 \mathrm{t} \cdot \mathrm{ha}^{-1}\right.$ and $\left.112.8 \mathrm{t} \cdot \mathrm{ha}^{-1}\right)$. Among intercrops treatment of 2011-12, SC + Gram had 1\%, 2\% and 4\% higher than SC + Potato, SC + Soybean and SC + Wheat. In 2012-13, unstripped cane yield of intercrops SC + Gram had 1\%, 2\% and 4\% higher than SC + Potato, SC + Soybean and SC + Wheat. During both the year of study significantly higher stripped cane yield $\left(102.43 \mathrm{t} \cdot \mathrm{ha}^{-1}\right.$ and $\left.100.9 \mathrm{t} \cdot \mathrm{ha}^{-1}\right)$ was noted in Sole SC and

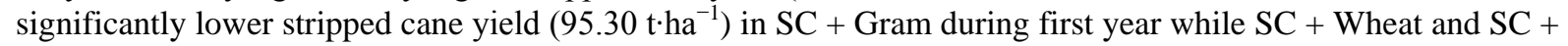
Soybean in second year. During 2012-13, stripped cane yield of Sole SC was statistically at par with SC + Potato. In first year of study, SC + Gram produced significantly $2 \%, 3 \%$ and $4 \%$ higher stripped cane yield than SC + Potato, SC + Soybean and SC + Wheat. During 2011-12 and 2012-13, land equivalent ratio (LER) of Sole SC and different intercrops in SC are presented in Table 1. However, LER of different intercrops were in range between 1.53 and 1.61 during study period. In other words, the intercrops yield advantages varied from 53\% to $61 \%$ respectively. It could be inferred, that advantage due to intercrops per hectare yields were equal to sole SC yields obtained from 1.53 to 1.61 hectares. The highest LER of 1.61 was recorded for SC + Wheat intercrop geometry during 2011-12 and 2012-13. The lowest LER of 1.53 and 1.54 was observed in SC + Potato intercrop treatment in both the growing season.

All yield parameters number of millable cane, cane diameter, unstripped and striped cane yield were noted significantly higher in sole SC compared than different intercrops in SC. Significantly higher yield attributes in sole SC was due to availability of sufficient soil nutrients and there was no crop competition [12] [17]. Among the intercrops, higher number of millable cane in gram was due to restorative in nature and lower number of millable cane was noted in potato [11]. The difference in cane diameter among different intercrops was attributed to nature of intercrops and available size of spacing area [18]. Raskar and Bhoi [8] also observed same trend due to variation in cane diameter with different intercrops. Significantly, higher unstripped and stripped cane yield was recorded in SC + Gram rather than other intercrops was due to uptake and availability of residual nutrients which was done by the plants roots [19] and row spacing [20]. The LER of different intercrops compared to their sole SC was found higher. This showed that different intercrops geometries were biologically more efficient as compared to their sole SC. It revealed that to produce the combined mixture yield by growing sole stands would need $53 \%-61 \%$ more land. Our results supported the findings of [21] [22].

\subsection{Different Intercrops Effects on Sugarcane Economics}

The economic benefits got from different intercrops SC planting was compared with the sole SC (Table 2). The data presented in Table 2 revealed that all the intercrop treatments increased the net return from sole SC. The highest net return (Rs. $450244 \mathrm{ha}^{-1}$ and Rs. $486429 \mathrm{ha}^{-1}$ ) was obtained from SC + Potato during 2011-12 and 2012-13. The next highest net return (Rs. $433763 \mathrm{ha}^{-1}$ and Rs. $415280 \mathrm{ha}^{-1}$ ) and (Rs. $431924 \mathrm{ha}^{-1}$ and Rs. 399735 $\mathrm{ha}^{-1}$ ) were given by the intercrops of SC + Wheat and SC + Gram during both the years, respectively. In 2011-12 and 2012-13, the lowest net return (Rs. $365121 \mathrm{ha}^{-1}$ and Rs. $333797 \mathrm{ha}^{-1}$ ) was noted at sole SC. During 2011-12 and 2012-13, maximum benefit cost ratio (5.40 and 5.02) was noted at sole SC while minimum benefit cost ratio in SC + Soybean (5.17 and 4.90) was observed. The sole SC produced 2\% - 4\% greater BCR than different intercrops.

The net return from different treatments was calculated by subtracting the total cost of production for each treatment from its gross income. Higher values of net returns/net income was obtained from different intercrops 
Table 1. Effect of different intercrops on number of millable canes, cane diameter, unstripped and stripped cane yield and land equivalent ratio of irrigated sugarcane (data of 2011-12 and 2012-13 growing season).

\begin{tabular}{|c|c|c|c|c|c|c|c|c|c|c|}
\hline \multirow{2}{*}{ Intercropping } & \multicolumn{2}{|c|}{$\begin{array}{l}\text { Number of millable } \\
\text { Canes }\left(\mathrm{m}^{-2}\right)\end{array}$} & \multicolumn{2}{|c|}{$\begin{array}{c}\text { Cane stem } \\
\text { diameter }(\mathrm{cm})\end{array}$} & \multicolumn{2}{|c|}{$\begin{array}{c}\text { Unstripped } \\
\left.\text { cane yield (t ha }{ }^{-1}\right)\end{array}$} & \multicolumn{2}{|c|}{$\begin{array}{l}\text { Stripped cane } \\
\text { yield }\left(t \cdot h a^{-1}\right)\end{array}$} & \multicolumn{2}{|c|}{$\begin{array}{c}\text { Land } \\
\text { equivalent ratio }\end{array}$} \\
\hline & 2011-12 & 2012-13 & 2011-12 & 2012-13 & 2011-12 & 2012-13 & 2011-12 & 2012-13 & 2011-12 & 2012-13 \\
\hline Sole SC & $14.3 a^{\Psi}$ & $14.0 \mathrm{a}$ & $2.08 \mathrm{a}$ & $2.02 \mathrm{a}$ & 121.8a & $120.2 \mathrm{a}$ & $102.4 a$ & 100.9a & 1.0 & 1.0 \\
\hline SC + Wheat & $13.4 \mathrm{c}$ & $13.1 \mathrm{c}$ & $1.96 \mathrm{e}$ & $1.92 \mathrm{c}$ & $113.6 \mathrm{e}$ & $112.8 d$ & $96.3 e$ & $96.0 \mathrm{c}$ & 1.61 & 1.61 \\
\hline $\mathrm{SC}+$ Gram & $13.9 b$ & $14.0 \mathrm{a}$ & $1.99 c$ & $1.96 \mathrm{~b}$ & $118.5 b$ & 118.1b & $99.7 b$ & $98.6 b$ & 1.56 & 1.55 \\
\hline SC + Soybean & $13.3 d$ & $12.9 \mathrm{~d}$ & $1.97 d$ & $1.96 \mathrm{~b}$ & 116.1d & $115.7 \mathrm{c}$ & $96.5 d$ & $95.9 c$ & 1.55 & 1.55 \\
\hline $\mathrm{SC}+$ Potato & $13.2 \mathrm{e}$ & $13.2 \mathrm{~b}$ & $2.01 \mathrm{~b}$ & $1.98 \mathrm{~b}$ & $116.9 \mathrm{c}$ & $115.9 c$ & $98.1 \mathrm{c}$ & 99.3ab & 1.53 & 1.54 \\
\hline LSD $p \leq 0.05$ & 0.033 & 0.035 & 0.035 & 0.035 & 0.048 & 2.062 & 0.064 & 2.06 & & \\
\hline
\end{tabular}

SC $=$ Sugarcane. SC + Wheat $=$ Sugarcane-wheat intercropping. SC + Gram $=$ Sugarcane-gram intercropping. SC + Soybean $=$ Sugarcane-soybean intercropping. SC + Potato = Sugarcane-potato intercropping. ${ }^{\Psi}$ Means separated by lower case letter in each column are significantly different among intercropping at $\mathrm{p} \leq 0.05$.

Table 2. Economics of various intercrop combination in September sown sugarcane (data of 2011-12 and 2012-13 growing season).

\begin{tabular}{|c|c|c|c|c|c|c|c|c|}
\hline \multirow{2}{*}{ Intercropping } & \multicolumn{2}{|c|}{ Gross Income (Rs'ha $\left.{ }^{-1}\right)$} & \multicolumn{2}{|c|}{ Total Cost $\left(\mathrm{Rs}^{\prime} \cdot \mathrm{ha}^{-1}\right)$} & \multicolumn{2}{|c|}{ Net Returns (Rs·ha ${ }^{-1}$ ) } & \multicolumn{2}{|c|}{ Benefit Cost Ratio } \\
\hline & 2011-12 & 2012-13 & 2011-12 & 2012-13 & 2011-12 & 2012-13 & 2011-12 & 2012-13 \\
\hline Sole SC & 448,175 & 416,910 & 83,054 & 83,113 & 365,121 & 333,797 & 5.40 & 5.02 \\
\hline SC + Wheat & 537,335 & 518,892 & 103,572 & 103,612 & 433,763 & 415,280 & 5.18 & 5.01 \\
\hline $\mathrm{SC}+\mathrm{Gram}$ & 532,823 & 500,659 & 100,899 & 100,924 & 431,924 & 399,735 & 5.28 & 4.96 \\
\hline SC + Soybean & 508,199 & 480,946 & 98,120 & 98,165 & 410,079 & 382,781 & 5.17 & 4.90 \\
\hline $\mathrm{SC}+$ Potato & 556,021 & 592,254 & 105,777 & 105,825 & 450,244 & 486,429 & 5.25 & 5.60 \\
\hline
\end{tabular}

SC = Sugarcane. SC + Wheat = Sugarcane-wheat intercropping. SC + Gram = Sugarcane-gram intercropping. SC + Soybean $=$ Sugarcane-soybean intercropping. SC + Potato = Sugarcane-potato intercropping.

than sole SC. Benefit cost ratio is another important economic parameter in which farmers are interested to see the gain in net returns with a given increase in total costs. Our findings supported the results of [11] who reported that all the intercrops gave higher net return and lower benefit cost ratio compared than sole SC.

\section{Conclusion}

Sugarcane is an important cash crop of Pakistan. It has pivotal role in the growth of sugar industry, uplifting the socio-economic conditions of farmers, and contributing in the economic development. Intercropping has been recognized an excellent and alternative way to future crop production under threat of land, population and high monetary returns. The present study revealed that the sole SC gave more than $6 \%$ and $13 \%$ higher stripped cane yield and CGR than all intercrop treatments. Higher values of LER were noted in SC + Wheat than other treatments. Maximum net returns was obtained in SC + Potato than other intercrops and sole SC while maximum BCR was noted in sole SC. Based on economics, it is recommended that resource poor farmers grow only sole sugarcane while resource rich farmers prefer to grow SC + Potato due to high returns.

\section{References}

[1] Akbar, N., Ehsanullah, Jabran, K. and Ali, M.A. (2011) Weed Management Improves Yield and Quality of Direct Seeded Rice. Australian Journal of Crop Science, 5, 688-694.

[2] Goverment of Pakistan (2012-2013) Economic Survey of Pakistan. Finance Division Economic Advisor’s Wing, Islamabad.

[3] Ali, M.A., Niaz, S., Abbas, A., Sabir, W. and Jabran, K. (2009) Genetic Diversity and Assessment of Drought Tolerant 
Sorghum Landraces Based on Morph-Physiological Traits at Different Growth Stages. Plant Omics Journal, 2, 214227.

[4] Ehsanullah, Jabran, K., Jamil, M. and Ghaffar, A. (2011) Optimizing the Sugarcane Row Spacing and Seeding Density to Improve Its Yield and Quality. Crop \& Environment, 2, 1-5.

[5] Malik, K.B., Ali, F.G. and Khaliq, A. (1996) Effect of Plant Population and Row Spacing on Cane Yield of SpringPlanted Cane. Journal of Agricultural Research, 34, 389-395.

[6] Sarwar, M., Gill, M.A. and Malik, K.B. (1996) Comparison of Pit and Trench Planting of Sugarcane at Different Fertilizer Levels. Pakistan Sugar Journal, 10, 11-13.

[7] Chattha, M.U., Ali, A. and Bilal, M. (2007) Influence of Planting Techniques on Growth and Yield of Spring Planted Sugarcane (Saccharum officinarum L.). Pakistan Journal of Agricultural Sciences, 44, 452-456.

[8] Raskar, B.S. and Bhoi, P.G. (2005) Dry Matter Accumulation and Yield Performance of Preseasonal Sugarcane Co 86032 with Intra-Row Spacings, Fertilizer Levels and Planting Materials. Journal of Maharashtra Agricultural Universities, 30, 150-153.

[9] Bhullar, M.S., Thind, K.S., Uppal, S.K. and Singh, K. (2008) Productivity, Profitability and Quality of Sugarcane (Saccharum spp.) Plant-Ratoon System in Relation to Planting Methods and Seeding Rate. Indian Journal of Agronomy, 53, 195-199.

[10] Misra, S.R., Ram, R.S., Kishan, S. and Singh, K. (1989) Effect of Intercrops on Dispersal of Smut (Ustilago scitaminea) Spores in Sugarcane Field. Indian Journal of Agricultural Sciences, 59, 114-117.

[11] Rana, N.S., Sanjay, K., Saini, S.K. and Panwar, G.S. (2006) Production Potential and Profitability of Autumn Sugarcane-Based Intercropping Systems as Influenced by Intercrops and Row Spacing. Indian Journal of Agronomy, 51, 31-33.

[12] Li, X., Mu, Y., Cheng, Y., Liu, X. and Nian, H. (2013) Effects of Intercropping Sugarcane and Soybean on Growth, Rhizosphere Soil Microbes, Nitrogen and Phosphorus Availability. Acta Physiologiae Plantarum, 35, 1113-1119. http://dx.doi.org/10.1007/s11738-012-1148-y

[13] Kannappan, K., Karamathullah, J., Manickasundaram, P. and Kumaraswamy, K. (1990) Studies on the Effect of Intercropping on Yield and Quality of Sugarcane. Cooperative Sugar, 21, 489-490.

[14] Razzaque, M.A., Mannan, M.A., Azam, S.A. and Ali, A. (1978) Mixed Cropping. The Indian Journal of Agricultural Sciences, 48, 324-327.

[15] Khan, G.S. (1986) Need for International Crosschecking and Correlation in Soil Analysis for International Classification Systems. Proceedings of the Twelfth International Forum on Soil Taxonomy and Agro-Technology Transfer: Soil Survey of Pakistan, 1, 276-293.

[16] SAS Institute (2008) SAS Online Doc 9.13. SAS Institute, Inc., Cary.

[17] Malik, M.A., Afghan, S., Ahmad, I. and Mahmood, R.A. (1993) Response of Sugarcane Cultivars to Different Doses of NPK Fertilizers in Somalia. Pakistan Sugar Journal, 7, 7-9.

[18] Cheema, I.A., Ayub, M. and Jabbar, A. (2002) Bio Economic Efficiency of Spring Planted Sugarcane as Influenced by Spatial Arrangement and Nutrient Management. Pakistan Sugar Journal, 17, 62-68.

[19] Cabangon, R.J., Tuong, T.P. and Abdullah, N.B. (2002) Comparing Water Input and Water Productivity of Transplanted and Direct-Seeded Rice Production Systems. Agric. Water Management, 57, 11-31. http://dx.doi.org/10.1016/S0378-3774(02)00048-3

[20] Bashir, S., Ali, A. and Yasin, M. (2005) Sugarcane Varieties and Row Spacing Effect on Sugarcane Traits. Pakistan Sugar Journal, 20, 18-20.

[21] Sharma, R.K., Bangar, K.S., Sharma, S.R., Gwal, H.B. and Verma, H.D. (1993) Studies on Intercropping of Pules in Spring Planted Sugarcane. Indian Journal of Pulses Research, 6, 161-164.

[22] Li, Z.X., Wang, J.W., Yang, W.T., Shu, Y.H., Du, Q., Liu, L.L. and Shu, L. (2011) Effects of Reduced Nitrogen Application on the Yield, Quality, and Economic Benefit of Sugarcane Intercropped with Soybean. Ying Yong Sheng Tai Хие Вао, 22, 713-719.

\section{Abbreviation}

$\mathrm{SC}=$ Sugarcane;

CGR = Crop Growth Rate;

LER = Land Equivalent Ratio;

$\mathrm{BCR}=$ Benefit Cost Ratio. 